\title{
Illicit pharmaceutical networks in Europe: organising the illicit medicine market in the United Kingdom and the Netherlands
}

\author{
Alexandra Hall ${ }^{1}$ - Rosa Koenraadt ${ }^{2}$. \\ Georgios A. Antonopoulos ${ }^{1}$
}

Published online: 29 March 2017

(C) Springer Science+Business Media New York 2017

\begin{abstract}
It has been widely suggested that the global market in counterfeit, falsified and illegally traded medicines has expanded at a tremendous rate in recent years, offering lucrative opportunities for criminal entrepreneurs with little legal risk. However, with a few exceptions, there has been little criminological research conducted on the trade's actors and organisation. Of the few studies that are available, most position the supply of these products in the context of 'transnational organised crime', often presupposing the overwhelming presence of large-scale, hierarchical structures in the trade. This article, based on two extensive research projects in the United Kingdom and the Netherlands, offers an account of the illicit supply of medicines in two European jurisdictions. The research outlines the nature and dynamics of the trade including the roles played by each national context as nodes in the global supply chain. The focus then shifts to the modus operandi, actors, online trade and social organisation in both countries. In contradistinction to the 'transnational organised crime' narrative, the empirical data outlined in this paper demonstrates that actors and networks involved in the trade are highly flexible and complex structures that straddle the categories of licit and illicit, online and offline, and global and local. This suggests that operations supplying illicit medicines vary largely in terms of size, reach, organisation and legality.
\end{abstract}

\footnotetext{
Alexandra Hall

Alexandra.Hall@tees.ac.uk

Rosa Koenraadt

R.M.Koenraadt@uu.nl

Georgios A. Antonopoulos

G.Antonopoulos@tees.ac.uk
}

1 School of Social Sciences, Business and Law, Teesside University, Middlesbrough TS1 3BA, UK

2 Willem Pompe Institute for Criminal Law and Criminology, Utrecht University, Boothstraat 6, 3512 BW Utrecht, the Netherlands 
Keywords Counterfeit medicines $\cdot$ Illicit medicines $\cdot$ Enhancement drugs ·

Organised crime $\cdot$ Online markets

\section{Introduction}

The market in counterfeit, falsified and illegal traded medicines is not a new phenomenon. Bate (2008) suggests that counterfeit pharmaceuticals have been around since the nineteenth century, when technology advanced and criminal entrepreneurs involved in counterfeiting began producing and distributing fake goods that offered the most lucrative opportunities with minimum legal risk. In recent years, it has been suggested that the trade is expanding at a tremendous rate (Blackstone et al. 2014; Interpol 2014; WHO 2012). The World Health Organization (WHO) first became aware of the public health issues associated with counterfeit medicines in 1985 and by 2010 they estimated that the global counterfeit pharmaceutical market had a turnover of 75 billion dollars (WHO 2012). Other more recent estimates claim a global market in illicit pharmaceuticals worth $\$ 200$ billion is in operation, highlighting a 90\% increase in revenues since 2005 (IRACM 2013). In Europe, according to a relatively recent study of 5000 European citizens across five nation states, $5 \%$ of consumers suspected that they had received a counterfeit prescription drug while $1 \%$ were sure they had. This would suggest that up to 12.8 million consumers were exposed to counterfeit medicines in those countries (Jackson et al. 2012). Moreover, the head of Interpol's pharmaceutical crime sub-directorate estimated that across the world up to 1 million people die each year after consuming counterfeit medicinal drugs, most of whom reside in developing nations (see Southwick 2013; Ossola 2015). Health risks are primarily present in cases of substandard medicines that contain unsafe or poisonous substances or lifesaving medical treatments that lack the effective ingredients (Dégardin et al. 2014; Buckley and Gostin 2013).

Despite the worldwide scope and seemingly increasing revenues associated with the trade, as well as the serious health implications it may pose for patients and consumers, criminological research remains limited. Of the few studies that are available, most position the supply of these products in the context of 'transnational organised crime', often presupposing the overwhelming presence of large-scale, hierarchical structures in the trade (UNICRI 2009; Attaran et al. 2011; Bate 2012; cf. Lavorgna 2014). It has been suggested that the proximity of illegal drugs markets and pharmaceutical markets - in terms of the active pharmaceutical ingredients and precursors - as well as the relatively lenient penalties for the trafficking of pharmaceuticals compared to other illegal drugs, has encouraged hierarchical, 'transnational' organised crime entities to engage in the trade. For example, the President of the World Anti-Illicit Traffic Organization and "fake medicines" Commission of the OECD Task Force on Charting Illicit Trade (TF-CIT) argued that counterfeiting and the illegal sale of pharmaceuticals is the "ideal transnational crime" (Delval 2015: 21) and that "Mafia-type organisations see the [fake medicine] market as an inexhaustible source of revenue without major criminal risk" (Delval 2015:15). Such representatives suggest the Russian Mafia, Chinese Triads and Colombian Cartels have moved into the trade. This is a view shared by law enforcement, the mainstream media and the legal pharmaceutical industry (see, for example, IRACM 2013).

Indeed, statistical representations and mainstream analyses should be met with some caution. Estimating the worldwide prevalence of counterfeit pharmaceutical drugs is 
problematic because detection remains difficult, while some pharmaceutical companies, nation states and consumers remain reluctant to report instances of counterfeiting (Newton et al. 2006; Chika et al. 2011). Another problem associated with statistical representations of the size and scope of the market relates to the broader trade in various categories of illicitly traded medicinal products and the on-going debate surrounding the terminology used to define them. There is a consensus that counterfeit medicines may pose a threat to public health. However, a terminological debate has arisen because, on the one hand, problems with illicit medicines are not confined to trademark infringement alone and, on the other, simply punishing intellectual property infringements does not take the public health risk into consideration (Dégardin et al. 2014). To date, there is no agreement on which terminology to use. As a result, various terms are in use in different contexts. These include: counterfeit medicines, which relates to products that infringe intellectual property rights (WHO 2012); falsified medicines, which is a broader term encompassing all pharmaceuticals falsely claiming to be an authentic product (IRACM 2013); substandard medicines that are genuine products that do not meet national regulatory standards (Buckley and Gostin 2013; Dégardin et al. 2014); and unlicensed pharmaceutical drugs, which can be generic or branded products legally produced abroad yet sold in a country with different licensing agreements in order to by-pass existing intellectual property laws and patents (MHRA 2013). To overcome this definitional confusion, in the current paper we use the term 'illicit medicines' to encompass all types of counterfeit, falsified and illegal traded pharmaceuticals. Therefore, this term includes the trade in adulterated and counterfeit medicines as well as medicines sold without a license.

Furthermore, the statistics and accounts available should not be taken at face value. They represent the political interests of various organisations and stakeholders and can be skewed to suit their interests; the economic interests of big pharma being a significant example here. There is a rich literature on the technical and substantive problems associated with positivist criminology and 'the numbers game' (see for example Young 2004). However, while acknowledging the problems associated with definitional issues and statistical estimates, this paper, taking into account all of the above product categories and a broad range of primary and secondary data sources, supports the contention widely accepted among experts that there is a large and growing market in illicit medicines. However, that it is impossible to quantify accurately. This simply proves the need for further research involving multi-sited, in-depth, data collection (Hall and Winlow 2015) that is capable of capturing a more detailed and accurate picture of the trade's complex dynamics.

Drawing on extensive data gathered as part of two large-scale projects in the United Kingdom (UK) and the Netherlands, the aim of this paper is to outline the modus operandi, actors and social organisation of the illicit medicine market in two European jurisdictions. In terms of organising illegal trades (see, for example, van Duyne 2003b) and criminal justice responses, the UK and the Netherlands are integral parts of what Europol (2008) regards as the 'Northwest hub of organised crime' in its Organised Crime Threat Assessment (OCTA): a region characterised by "major transport infrastructures, different tax regimes, geographical proximity to various Member States and a flourishing economy which offers possibilities that can and are exploited by organised crime" (Europol 2008: 33). As will become clear, in the context of the global trade in illicit medicines, both national contexts act as integral hubs of 
production, transit and distribution. Therefore, the article offers an in-depth account of the illicit market in pharmaceuticals in two national contexts that are also essential nodes in the global supply chain. The paper provides a unique insight into how illicit suppliers of medicines in both countries circumvent and exploit national and virtual borders. In contradistinction to the 'transnational organised crime' narrative, the empirical data outlined in this paper show that actors involved in the illicit supply of medicines in the two contexts often belong to loosely structured networks. These networks straddle what are often presented as the dichotomies of licit/illicit, online/ offline and global/local, making use of variations in national regulatory standards and economic opportunities over borders, as well as increasingly innovative digital commercial techniques. This suggests operations supplying illicit medicines vary largely in terms of size, reach, organisation and legality.

\section{Methodology}

This paper is based on two in-depth research projects exploring the illicit medicine trade in the UK and the Netherlands. The original impetus for this analysis came about during a number of discussions that took place between the researchers at related academic, law enforcement and industry conferences. Although the projects were conducted separately, the research teams determined a great deal of similarity in each national context that warranted further exploration and discussion in the academic literature. Indeed, it is becoming increasingly important to offer multi-sited accounts of social actors and criminological phenomena (Falzon 2009).

The aim of the first study was to explore and examine the size, scope, nature and dynamics of the illicit medicine market in the UK, focusing on the demand and supply sides. It was primarily qualitative in nature and involved collecting in-depth data using a number of integrated methodological techniques in both online and offline contexts. First, primary data were collected via a UK-based virtual ethnography, which involved the researchers immersing themselves in a number of online communities and environments over time. This was done on a regular basis between June 2013 and March 2014, as well as on subsequent intermittent occasions. With regards to the supply-side in particular, this method was used to collect data from various online sellers and sites, which was then analysed, pooled and categorised in order to look for common patterns. The virtual ethnography allowed the researchers to collect rich data from online sites used for supply and, when accompanied by data collected from other sources, to begin to analyse the networks that have proliferated throughout the various stages of the trade that caters for consumer demand in the UK, as well as identifying connections between traders based in the UK and abroad.

Second, data were collected via traditional ethnographic methods. The offline ethnography was primarily conducted in a gym in the Northeast of England in which the use and trade of anabolic steroids is widespread. The gym setting presented the opportunity to acquire knowledge regarding the 'illicit' use and supply of performance and image-enhancing drugs (PIEDs), predominantly anabolic steroids, as well as a number of other pharmaceutical products (see Antonopoulos and Hall 2016). Further observations and interviews were conducted with a range of consumers, suppliers and professionals outside of the gym setting, who predominantly reside in two urban areas 
in Northeast England. In the adoption of an ethnographic approach (see Hall forthcoming), the fieldwork required building rapport in order to observe and experience a social environment alongside research participants over extended periods. Having lived in these locales for a number of years helped the researchers who have personal networks and key contacts in the areas and felt confident in their ability to have an 'immersive experience' (see Desmond 2016; see also Hobbs 1988; Adler 1998; Winlow 2001). In total, 45 semi-structured interviews took place. Interviews were conducted as free-flowing conversations with participants on a series of occasions between January 2014 and February 2015. Most of the interviews were quite informal and brief, in which a few questions were asked yet usable data were received (see Schwalbe and Wolkomir 2003).

Third, data were collected from a range of other sources in order to effectively triangulate and add credibility to the findings (Thomsen 1998). Data from judicial and investigative cases, statistics from law enforcement and regulatory agencies, interviews with relevant stakeholders and enforcement officers, and secondary media and academic sources were gathered and analysed. Specifically, data from the UK Medicines and Healthcare products Regulatory Agency (MHRA) - the primary regulatory and enforcement agency working in this area in the UK - the National Crime Agency (NCA) and Interpol were collected. This included gathering statistics and conducting semistructured interviews and general discussions with practitioners in these organisations in the UK. Six investigative and judicial case files relating to pharmaceutical crime were accessed at the MHRA. These files were concerned with some of the most serious cases in the UK to date. Each case file included detailed intelligence and a picture of the nature and dynamics of the supply of illicit pharmaceutical products, including information on the social organisation of the trade, its financial management, and a range of marketing and advertising tactics adopted by illicit pharmaceutical traders.

The second study primarily focused on the supply and demand processes associated with the trade in illicit medicines in the Netherlands. Primary in-depth data were gathered by using a multi-method approach that combined quantitative and qualitative research methods. First, court cases were analysed to discern patterns of the sale or trade of illicit medicines. In the Netherlands, a range of regulatory institutions generally conducts investigations on the illicit pharmaceutical trade. Therefore, 69 Dutch case files were selected and analysed at the Health Care Inspectorate (Inspectie voor de Gezondheidszorg), the Public Prosecution Service (Openbaar Ministerie) and the Fiscal Information and Investigation Service (Fiscale Inlichtingen- en Opsporingsdienst). Through wiretapped conversations, interrogations and other materials, the case files contained in-depth information on the types of medicines traded, methods of supply, criminal cooperation, social organisation of the trade and market dynamics.

Second, 78 semi-structured interviews were held with suppliers $(N=30)$, consumers $(N=9)$ and various officials $(N=38)$. The interviews with consumers and suppliers provided in-depth knowledge on their activities, ideas and motives. The respondents were recruited online or in person by snowball sampling (Decorte and Zaitch 2010; Davies et al. 2011) and were usually spoken to during several occasions in order to increase trust (see also Koenraadt 2012, 2015). The interviews took place in the work environment of the respondents, in public places such as restaurants or bars, or over the phone. All interviews lasted between one and three hours. Almost all were recorded with a voice recorder and transcribed at a later stage. 
Third, an online analysis of 17 websites and discussion platforms on which medicines were sold and discussed was conducted. The online analysis revealed additional information on the types of illicit medicines offered online, the language used, payment systems, shipping methods and contact information. Fourth, quantitative data were obtained through a survey study in the Netherlands. A prevalence study was conducted among a panel of 50,860 Dutch respondents, after which an in-depth study among 985 consumers of illicit medicines took place. The in-depth study included 447 respondents that purchased medicines online and consisted of 60 questions divided into various themes, such as purchasing behaviour, satisfaction, motivations and risk perception (see also Koenraadt and de Haan 2016).

The fact that suppliers, traders and consumers in illicit markets generally try to remain hidden from law enforcement is banal but important to remember. Qualitative and online data sources can reveal a lot of detailed information about these evasive market actors, but it cannot be generalised to a larger population. Furthermore, official data usually contains selective information (Hobbs and Antonopoulos 2014). Therefore, both research projects have combined multiple data sources in order to triangulate the research data and overcome the limitations associated with each individual research method. This paper draws on findings from all of the data sources above. Focusing on the supply side, it will integrate these sources and include interview data and summarise several exemplary case files from both research projects. These cases have been chosen because they are the most representative of the data obtained by using all the methods outlined above in both the UK and the Netherlands. The aim of presenting these cases is for illustrative purposes.

\section{The illicit medicine market in the UK and the Netherlands}

The global market in illicit medicines concerns almost all types of pharmaceutical drugs, ranging from sexual enhancers to antibiotics and anticancer medication (WHO 2012). In the Global South, illicit lifesaving medicines used to treat diseases such as malaria, HIV and tuberculosis are supplied on the largest scale, while in the Global North, expensive products such as lifestyle medicines or newly patented medicines are more often illicitly distributed and sold (Wertheimer and Wang 2012; Newton et al. 2006). These lifestyle medicines - also referred to as performance and image enhancing drugs (PIEDs) or enhancement medicines - lie on the borderline between health needs and lifestyle choices. The category includes sexual enhancers, anabolic steroids, hormones, weight loss medicines and products to treat hair loss (Gilbert et al. 2000; Young 2003; Evans-Brown et al. 2012; Koenraadt 2012, 2014).

Data collected from the MHRA relating to enforcement operations, including seizures during raids from 2009 to 2014, identified the main illicit medicines currently being supplied in the UK as erectile dysfunction drugs (90\%), anabolic steroids, weight loss and hair loss medicines (see also MHRA 2013). During the fieldwork undertaken both online and offline a similar picture emerged but thriving markets in illicit sedatives, opioid analgesics, antibiotics, psychiatric drugs, fertility drugs and stimulants were also identified. The UK research identified a particularly large market in illicit erectile dysfunction medicines and anabolic steroids (see also Yar 2008). For the basic reasons of saving embarrassment and avoiding stigma (see Cordell et al. 1996; Albers- 
Miller 1999), most people prefer to order Viagra and other drugs used to treat erectile dysfunction online, and a large proportion of these products are counterfeit, falsified or illegally traded. In gym and bodybuilding subcultures in the UK the demand for steroids and various appetite suppressants and supplements is high, and there is evidence suggesting a large counterfeit market in operation. The market for anabolic steroids in the UK has in some respects moved online, particularly for those consumers who are not embedded in the gym and bodybuilding scene and do not have access to suppliers offline (see also Antonopoulos and Hall 2016). Other factors contributing to the demand for various illicit medicines include the privatisation and individualisation of healthcare practices, and pharmaceutical drug diversion for recreational purposes and prescription drug misuse (see Hall and Antonopoulos 2016).

The Netherlands resembles the UK insofar as most of the medicines traded are aimed at the lifestyle or 'enhancement' market. With a high demand for cheaper medicines or medical supplements that are rare in the Netherlands, a lively trade primarily exists in medicines that are being used for non-health and non-lifethreatening conditions, and an increasing proportion of the Dutch population purchases these medicines online. In 2015, an estimated $10.2 \%$ of the population in the Netherlands had purchased medicines online, with at least $1.6 \%$ having purchased unofficial medicines (Koenraadt and de Haan 2016). Sexual enhancers, weight loss medicines, and sedatives are by far the most popular illicit medicines purchased online (Koenraadt and de Haan 2016). These findings coincide with literature and seizure statistics of the Dutch customs laboratory, in which sexual enhancers are the foremost seized medicine. In a recent study by the National Institute for Public Health and the Environment (Rijksinstituut voor Volkgezondheid en Milieu) based on sewage measurements, it was estimated that at least $60 \%$ of the consumed sexual enhancers in the Netherlands were not legitimately obtained (Venhuis et al. 2014). While some consumers are actually aware of the risks and may wittingly purchase enhancing substances from unlicensed sources, others might not be aware they are consuming counterfeit or adulterated medicines (Venhuis et al. 2011; Koenraadt 2012; Van de Ven and Mulrooney 2016).

A full examination of the cultural, psycho-social and economic factors contributing to the demand is beyond the scope of this article (see Hall and Antonopoulos 2016; Koenraadt 2012). However, in short, we have found that the continuous search for enhanced bodily capital, improved performance and the transformation of the social self and identity is the main cultural context in which we now witness an increasingly high demand for various human enhancement drugs - both licit and illicit - in Western Europe (see Evans-Brown et al. 2012; Cederström and Spicer 2015). Due to the high demand and widespread online availability of these medical substances, the consumption of illicit enhancement medicines has become a challenge for public health (EvansBrown et al. 2012; Kimergård et al. 2014).

Our research found that apart from a few small-scale operations, illicit medicines are generally not produced in the UK and most are imported through a variety of trade routes. Previous research suggests that a large proportion of illicit medicines entering the UK are produced in India, Pakistan, China and Russia (see Yar 2008; Hall and Antonopoulos 2016). Illicit medicine suppliers target the UK as both a transit zone and end-user market. As a transit zone located between producers and consumers in the USA and Western Europe packages reaching the UK can be redirected with a greater degree of 'legitimacy'. This results in a large volume of illicit medicines transiting 
through the UK, some of which also target the end-user market because the higher price of medicines and the heightened consumption patterns in comparison to most other European countries produces higher profits. Enforcement officers informed us of the increasing number of small-scale packages that present a reduced financial risk for traders concerned about the risk of interception:

"We are now seeing much smaller parcels coming through the post from overseas, we expect this is in response to large parcels not wanting to be risked anymore." (Interview with British law enforcement agent)

Within the network of general European drugs markets, the Netherlands is recognized for its high levels of domestic production and exportation of cannabis and synthetic drugs, and for its significant role as a transit country within the illegal drugs trade more generally (UNODC 2013; EMCDDA 2016). In the illicit medicine trade, the Netherlands is a producing, transit and end-user market. Findings from the Netherlands suggest that the majority of illicit medicines entering the market are likewise manufactured in China, India, Pakistan or Thailand before being broken up into a number of smaller scale packages. However, in recent years, officials in the Netherlands are facing an increase in imported raw pharmaceutical materials and small production centres:

"Since $1^{\text {st }}$ of January, 2014, the import of bulk raw materials for the purpose of fabricating medicines has been made illegal. These raw materials are overall originating in China, while most of the packages being sent from India contain the final medicines" (Interview with Dutch law enforcement agent).

Up until January 2014, the import of raw materials was poorly regulated and enforced, while importation of manufactured illicit medicines was more strictly controlled. As a result, increasing bulk powder and raw materials were being imported. According to law enforcement officers, the production of medicines within the Netherlands often occurs in conjunction with the manufacturing of other illegal drugs, such as ecstasy, or the production of PIEDs, such as steroids.

\section{Modus operandi and actors}

It is generally understood that the global trade in illicit medicines is widely dispersed in geographical space, following a typical pattern from production and distribution through to consumption. By means of a blooming and expanding pharmaceutical industry in both legitimate and illicit medicines, production centres are to be found mainly in South Asia (India and Pakistan), China, Hong Kong, Russia and Latin America, and distribution tends to be at its most active in large networks in parts of the Middle East, Africa and Central Europe (Hall and Antonopoulos 2016). In Europe, the legal pharmaceutical supply chain is largely safe because of effective control policies set by national authorities (Bate 2012). Thus, the illicit supply of medicines primarily takes place throughout 'hidden', illicit and online supply chains that span the globe, with limited products infiltrating the legitimate and strictly controlled supply chain (ibid; see also Lavorgna 2014). 
Therefore, the supply chain of a batch of illicit medicines consumed in the Netherlands or the UK is likely to follow similar patterns and trading routes, with the medicines mainly being produced in Asian countries, especially China, India or Pakistan and distributed through other transit countries (e.g. Spain, Russia, Hungary). For example, as the following case suggests, the products are produced in Pakistan and India, trafficked to transit hubs after which they arrive in the Netherlands. The case shows patterns in the importation of counterfeit medicines similar to other cases. Multiple addresses, PO boxes and fake names are used and large amounts of pharmaceuticals are divided over small shipments.

\section{Case 1 (NL): Wholesale business}

\section{Years of alleged offence: 2008-2013}

A large-scale illicit medicine business was discovered after various parcels containing counterfeit medicines being shipped from the Netherlands to the UK were confiscated. The investigated wholesale business was centred around a key player who would primarily receive medicines from a wholesaler in Pakistan. The key figure was cooperating with three main fellow suspects in the Netherlands. The business mainly involved prescription medication such as Diazapam, Ritalin, Bromazepam, Oxycodon, and Iomax. The wholesaler in Pakistan would send packages to the Dutch main suspect, from which the medicines were sold to consumers, suppliers, resellers and middlemen, and sent to addresses in the Netherlands, Belgium, Germany, Denmark and the USA. Medicines were sent and received through various post boxes in different parts of the city. Buyers had to transfer money to a designated bank account, by referring to their own first name, while cash could be sent to different PO boxes.

\section{Source: Dutch Public Prosecution Service}

It appears that although the cases from law enforcement relating to activities and actors based in the UK and the Netherlands highlight a number of local and national particularities, global connections are necessary in order to obtain the products to sell. Therefore, global networks of the physical and financial flows of illicit medicinal products are important for our analysis. Another example is reflected in a UK case, in which a number of suspects whose bank accounts would be used to launder money were known to be living in Thailand, Greece, Turkey and Spain. The units and businesses implicated in the operation were based throughout the UK while the accounts and banking facilities were scattered across the globe.

\section{Case 2 (UK): Family and friends}

Years of alleged offence: 2004-2011.

In 2004 a business purported to be trading in fishing tackle, electrical goods, cosmetics and jewellery was found to be selling both unlicensed and counterfeit erectile dysfunction drugs online. It was later found that the same operation was 
selling counterfeit Viagra and Valium offline. This was a large and complex operation involving twenty-one suspects with various organisational roles who were members of a close knit circle of family and friends based in two teams: one in the North and one in the South of England. Over 100 different merchant and business accounts were implicated in the case. This included the accounts of two of the main suspects' mothers, one based in Greece, the other in Turkey. In the later stages banking moved offshore to Panama and Belize, where less questions were asked. A number of front companies were also set-up in order to provide business documentation if requested by the banks. Evidence gathered highlighted (1) £11 million in various bank accounts and (2) receipts showing an average turnover of $£ 60,000$ per week, suggesting an annual turnover of £3 million.

Source: MHRA files.

An important recurring aspect in the majority of the court cases as well as the other data obtained in both countries is the interface between legitimate and illegitimate supply. For example, various cases demonstrate how a legitimate company can serve as a shield for the sale of illicit medicines. The fact that the suppliers own a legitimate company, or are employed by one, provides the opportunity to use the ambiguity of the legitimacy of their products to conceal illicit activities (Bowman 2008; Kleemans and Van de Bunt 2008; Passas 2003). Suppliers on all levels can operate under the guise of a legitimate company and sell illicit medicines for extra income, while using it to expand their network and launder profits. In a large proportion of the 69 court files in the Netherlands, the suppliers involved had no criminal record. Instead, they were involved in various official companies involved in food supplement supply, national and international trading and the healthcare sector. At times, trading illicit medicines was linked to other criminal offenses, such as the illegal drugs trade (ecstasy, cocaine), other forms of counterfeiting (clothes, jewellery, cosmetics), or corruption and fraud in sectors such as healthcare. For example, one Dutch case outlines the business of a fraudulent doctor, who purported to be licensed to hold surgeries while selling counterfeit weight-loss medicines.

\section{Case 3 (NL): Fake doctor}

\section{Years of alleged offence: 2011-2014}

This case involved a male suspect who posed as a certified medical doctor. With several patients he travelled to China for surgery, where the patients had to pay large amounts of money for their medical operations. He conducted smaller surgeries himself, without having a medical license. Besides that, the suspect was accused of prescribing counterfeit weight-loss medicines to his patients. During a house search, 13,680 counterfeit weight-loss capsules were found, 13,775 sachets of weight loss coffee, and 71,710 other illicit weight loss capsules. Shipping receipts were found that contained evidence of at least $620 \mathrm{~kg}$ and $285 \mathrm{~kg}$ of weight loss medicines sent from China to the Netherlands. 
The data from both research projects reveal that many cases of illicit medicine supply are examples of opportunistic crime (see Ruggiero 2000). This is committed by individuals and groups who already have some of the necessary infrastructure in place - businesses, contacts in the pharmaceutical industry, payment facilities and so on - to assist them in the supply of illicit medicinal products. Frequently, these existing businesses (gyms, shops, healthcare practices, online shops) are used as front companies and existing payment facilities are used for the illegal sale of medicines. This is equally shown in UK cases in which actors ran their illicit medicine business from legitimate business premises, taking advantage of a number of existing business contacts. Cases included an operation selling illicit medicines packaged as herbal remedies from a newsagent and online, operations running an online pharmacy alongside an Indian call centre and quad bike business, business partners running an illicit medicine business online in the UK alongside a pharmaceutical production factory in India, gym owners/business partners who saw the opportunity to sell steroids and related prescription drugs used to 'bulk up' to customers at their gym before expanding their business online, and suspects with previous involvement in the pharmaceutical industry operating front companies and well-versed in the use of offshore banking.

Furthermore, the dispersal of such networks allows the circumvention of legal and regulatory systems. On occasion both the consumer and supplier - if based abroad in a country with an applicable license - are engaging in a completely legal business transaction. A prevalent example in the UK is Kamagra, a generic version of sildedfanil citrate (most commonly known by its brand name Viagra), which is a licensed medicine produced and sold to treat erectile dysfunction in India. In the UK, Kamagra is an unlicensed drug, yet is not controlled under the Misuse of Drugs Act. Therefore, it can be shipped to a UK consumer by an India supplier without either party engaging in a criminal act.

Thus, the blurred boundaries between the legitimate, grey and illegitimate trading flows are highly reflected in the market for illicit medicines. We are not referring to a case of an illegal trade emerging in the shadows of a legal trade, but the constant and normalised blurring of the boundaries between legal and illegal businesses throughout various stages in the supply chain to the point that they often become symbiotic (see Passas 2002; Naylor 2004; Paoli and Donati 2014). Put in Ruggiero's (1996) terms, the trade is another example of a 'dirty economy', in so far as crime and the legal sector appear to mutually promote entrepreneurship. It is interesting to note that the legitimate actors are neither exploited by criminal networks nor simply provide support to the criminal networks knowingly or unknowingly (see also Ruggiero 2003; van Duyne 2005; Vander Beken 2005). They are what Morselli and Giguere (2006: 185) call 'critical actors', who drift from legality to illegality and back always within the confines and protection of their legal business (see also Kleemans and Van de Bunt 2008).

\section{The online trade}

Increasingly innovative and accessible information and communications technologies (ICTs) play a crucial role in the magnitude and nature of this and other illicit transnational commodity markets. In particular, late-modern technologies have not only accelerated the tempo in which new pharmaceutical products are introduced (Crary 2014) but have also compressed the spatial and temporal features of illicit markets. On 
all levels, the illicit medicine market is flourishing on a variety of websites, such as online pharmacies, business-to-business websites, social media sites and darknets (see also Hall and Antonopoulos 2015, 2016; Di Nicola et al. 2015; Koenraadt 2015). For example, in this Dutch case, online pharmacies were used for the retail supply, while ecommerce was employed for the wholesale:

\section{Case 4 (NL): Family members}

Years of alleged offence: 2010-2012

Between January 2010 and June 2012, multiple packages, parcels and envelopes confiscated by customs contained weight loss product Slimex and counterfeit medicines such as Viagra, Cialis and Levitra. In total 130,000 medicines related to this case were confiscated. The business revolved around two male family members and one fellow suspect. They communicated online with two manufacturing companies in China, where the production of Slimex medicines and packages took place. Packages and parcels were sent to various addresses related to the main suspect, such as addresses of family members, his company, business partners, and resellers. Medicines were sold online under the guise of official, legitimate or natural sexual products and weight loss methods, all registered with official account numbers. At least 14 different websites with legitimate payment systems were used for the sale of the medicines, including online pharmacies and e-commerce websites.

\section{Source: Dutch Public Prosecution Service}

Wholesalers, vendors, traders and consumers are easily able to order and sell illicit medicines online from a geographical distance without the need for face-to-face contact. As a result, some actors involved in the trade - although they function in collaboration with networks of other actors - never physically meet their suppliers or customers, and exchange data and facilitate financial transactions from the privacy of their own homes and legal business premises. This was particularly apparent on social media websites when traders connected to online wholesalers were found to be conducting the entire process from wholesale to retail online, essentially bypassing criminal brokers who operate online pharmacies.

The complex and flexible organisational network emphasises another pattern emerging from the data of both our studies: the blurring between online and offline processes in the context of the trade. Overall, suppliers and consumers do not specialise in online or offline trading methods. Rather, both online and offline trading methods are used in combination:

\section{Case 5 (UK): Gym business}

Year of alleged offence: 2007-2010

A police investigation found 2 suspects selling anabolic steroids and prescription-only medicines both online and from a gym in Essex. Suspect 1 (who had been prosecuted in the past in relation to similar offences) ran and 
owned a gym frequented by those interested in bodybuilding. He began selling anabolic steroids and other prescription drugs he sourced from China to customers in his gym and over the Internet on a website he set up, which was purported to be selling protein shakes and supplements. He also set up merchant banking facilities to receive payments. Suspect 2 was an associate of Suspect 1 and worked in his gym. He also set up his own website to conduct similar activities. He would eventually buy Suspect 1's online business for £15,000.

Source: MHRA case files

Various online sites and payment facilities are simultaneously used by the same operation to sell illicit medicines. The actors in another UK case, for example, traded via email, a personal website set up as an online pharmacy, classified advertising sites and well-known online marketplaces. However, all sales were not necessarily completed online; the same suspect marketed products and completed orders over the telephone and in a shop using the PayPoint machine. At times these online and offline practices are intentionally alternated to diminish the chances of detection. For example, as one illegal trader in the Netherlands highlighted:

"The control is now stricter and stricter, so my website is hosted outside Europe. Right now my website runs through India, so that they cannot get rid of mine. And you see, the justice department is focusing on this topic now, so we are not running everything through the internet anymore. Customers can usually find us online, and then they will receive a telephone number to place their orders" (Interview with Dutch illegal trader).

Similarly, in terms of payments, e-commerce has simplified the process of buying and selling illicit goods, but also borrowing/renting the bank accounts of friends and family members and setting up offshore banking facilities are often used to obscure the virtual 'paper trail'. Furthermore, in many instances those who produce and trade illicit medicines offline buy their primary materials online so their (offline) business is simply an extension of the online supply chain (see Management Today 2013). Driven by the explosion in internet usage globally, e-commerce is booming in legitimate and illegitimate healthcare sectors. The Internet therefore acts as a 'force multiplier' (Yar 2006: 10) in the advertising and marketing dimension of the trade by making it easier to set up sites and complete commercial transactions. However, although technological improvements have vastly expanded the market for illicit pharmaceuticals, connecting traders and consumers worldwide, at times the trade is clearly embedded in physical, offline locations, such as shops, markets and gyms (see Koenraadt 2015; Antonopoulos and Hall 2016; Van de Ven 2016). Indeed, as the cases above and other data illustrate, operations usually make use of a mixture of both online and offline tactics and techniques.

\section{Social organisation}

The social organisation of the operations analysed in both the studies suggest that connections in the trade are often made between friends, business partners and family 
members, or online. Case 2, summarised above, offered insight into the social organisation of a UK-based operation that was described as a 'jigsaw of individuals', male and female, who were members of a close-knit group of family members and friends acting as teams situated in different geographical locations. This network of actors maintained a number of core organisational functions, which included distinct individuals or teams in close contact who play different roles within and between these organisational functions. This included purchasing stock, operating storage and packing units, re-routing postal packages, transporting the drugs, supporting and maintaining the ICTs used to advertise and trade online, or setting up and running offshore baking facilities and front companies. Smaller networks around friends, family and business partners were found in abundance in both pieces of research. Networks involving family members and friends, business partners and university students were identified:

\section{Case 6 (UK): Students}

Year(s) of alleged offence: 2011.

In 2011 the UK Border Agency began inspecting consignments destined for three separate addresses in the UK; one in London and two in Loughborough. The packages were being sent from an address in India. This led to the arrest of two male suspects. Both defendants were part of a large scale conspiracy to import unlicensed and counterfeit medicines used to treat erectile dysfunction and hair loss into the UK, with some for further onward distribution to other parts of Western Europe, including the Netherlands. This involved a number of other suspects who were implicated as drop shippers. Both defendants were students at Loughborough University and had previously shared an address. One male was suspected to be the owner or partner of a factory in Baroda, India, being used to supply the products. Seizures uncovered approximately 110,000 falsified medicinal products (including Sildenafil, Tadalafil and Finasteride) at three addresses. The total value of the products recovered was $£ 610,000$. Western Union had been used for payments.

Source: MHRA files.

However, there are also highly unorganized schemes of smaller businesses and individual entrepreneurs that acquire pharmaceuticals directly from the manufacturer and thus skip various levels of the distribution chain. For example, drop shippers are the ideal illustration of such semi-autonomous actors operating in networks. Our research across the UK and the Netherlands has shown cases of drop-shipper resellers who are not necessarily connected to a distributor but answer adverts they find online and become involved without ever meeting in person. Drop shippers are involved in rerouting goods in the supply chain and are usually paid per shipment. They receive orders from the main organisational actors to re-direct to other parts of the EU. Suspects were usually selling to customers and liaising with numerous suppliers via a number of email addresses.

Thus, especially because of the blurring boundaries between legitimate and illegitimate supply, and widening online opportunities, our data highlights that overall, 
networks of friends and family, as well as of smaller businesses and individual entrepreneurs are involved in the trade. On the one hand, actors are able to obtain pharmaceuticals directly from the manufacturers. On the other hand, some networks include various middlemen and traders who fulfil specific roles and wholesale import is related to high-end suppliers who trade the products in large quantities. Because wholesale suppliers are also moving towards the method of importing smaller quantities, the same tactics are employed but with more variation in scale.

\section{Discussion}

There has been a perception that the global illicit medicine market is controlled by rigid, hierarchical, Mafia-type organisations. However, what clearly emerges from the two extensive research projects upon which this paper is based is that the market is facilitated by numerous small groups with varying coherence, and in the case of largescale smuggling, networks, (see, for example, Reuter 1983; Potter 1994); although the presence of complex, flexible and shifting 'social entities' related to the business can still be discerned. There is no 'organisation' or 'authority', which enforces or directs practice to supposedly 'members' of such an 'organisation'. Instead what does exist in the described illegal markets are networks of action-oriented individuals, who in most instances act for their personal interests and often on improvisation. Networks are the best vehicle for these illegal businesses since "...the most reliable flow of supply comes from myriad of small scale, uncoordinated firms. Having diverse sources for the illicit commodities means that if the regulators knock off one or a few, the market continues uninterrupted" (Beare and Naylor 1999: 17). In some situations, the market is facilitated by skilful, sole individuals especially when the scale of the operations and the quantities of merchandise concerned are small (see von Lampe 2007; Paoli 2002).

Overall, the image of the business that emerges from our examination of trade in the UK and the Netherlands is consistent with views of organised criminal activities as rather less robust from an organisational viewpoint. Our findings are in accordance with "a growing body of literature on organized crime in Western countries that shows that the great majority of illegal exchanges in Western countries are carried out by numerous, relatively small and often ephemeral enterprises" (Paoli 2016: 11) that assemble on the basis of necessity and opportunity rather than authority and formal rationality (see Pearson and Hobbs 2001; Bruinsma and Bernasco 2004; Hobbs 2013; Antonopoulos and Papanicolaou 2014). With some exceptions the illicit medicine trade displays mostly a technical division of labour, according to skills and competencies without further elements of organisational direction or centralisation. Within this context, at the core of collaboration between and among entrepreneurs involved in the illicit supply of medicines often lie family or kinship relationships, and existing legitimate business connections that constitute a trust basis for criminal cooperation (von Lampe and Johansen 2004), and their incorporation is a very effective strategy to reduce the vulnerability of illegal enterprises to law enforcement action. What von Lampe (2007) calls a 'social microcosm' of illegal entrepreneurs is of critical importance to the success of a trading scheme (see also van Duyne 2000; Edwards and Levi 2008). The research has also identified business relationships generated and sustained online. These schemes might mirror offline schemes but without actors having to meet in person. 
Our findings suggest that the trade in illicit medicines, an essentially 'market-based', entrepreneurial criminal activity (see Naylor 2003), exemplifies the idea that crime and commercial activity are 'half-brothers' (van Duyne 2005: 2). The illicit medicine market in the UK and the Netherlands offers a very clear indication of the ways in which the legal and the illegal are blurred. There is a wide perception that there is a clear boundary between the legal and the illegal market (van Duyne 2003b); a perception that official and media accounts uphold. However, illegal marketers exploit opportunities for profit and benefit from the legal sector in various ways, just as legal businesses can also benefit from 'organised crime'. The illicit markets presented in the current article are not always antagonistic or injurious (Passas 2002; see also Beare 2003) to their legitimate counterparts or the legal sector as a whole. Criminality is not completely unknown to legitimate businesses and neither do criminals always live off legitimate business in a parasitic way (see von Lampe 2016). Ruggiero's concept of the 'dirty economy' mentioned earlier posits the existence of objective common interests linking together legitimate business and criminal conduct (Ruggiero 1996; Ruggiero 2003). This highlights the essential and ubiquitous links between both legal and illegal sectors of the pharmaceutical business in global capitalism as a networked system of accumulation (Hall and Antonopoulos 2016; see also Nordstrom 2007; Hudson 2015).

Locating the British and Dutch markets in illicit medicines in the global supply chain, it becomes clear that both the UK and the Netherlands are integral yet distinctive hubs of production, transit and consumption in the organisation of the trade in the North-West region of Europe (Europol 2008). Both countries are host to a large proportion of end-consumers. The UK specifically serves as a transit country and the Netherlands, while retaining its function as a transit country, is also increasingly used as a manufacturing hub. Our understanding of the organisation of the trade is best conceptualised as a 'glocal' networked market operating in the contexts of global trade liberalisation and technological innovation running in parallel with everyday national and local economies that straddle the legal and illegal (see Hobbs 1998; Hobbs and Dunnighan 1998; Hall and Antonopoulos 2015). Referring to the particular market as the ideal transnational crime, as we saw earlier, would operate more as an "additional fear arouser" (van Duyne 2004: 6; 2003a), rather than reveal the more essential and complex aspects of the business mentioned above. The trade in illicit medicines is constantly evolving in the broad contexts of a number of complex and interacting legal, technological, economic, cultural, social and psychological processes and forces. Implementing highly effective enforcement in Europe will continue to present challenges, with suppliers increasingly able to adapt to and exploit new technological opportunities and trading methods as the demand for illicit pharmaceuticals continues to grow.

\section{Compliance with ethical standards}

Funding This work was partly supported by the European Commission [Grant number: HOME/2011/ISEC/ AG/FINEC/4000002221 'FAKECARE'] and the European Union's Education Audio-visual and Cultural Executive Agency's Erasmus Mundus Fellowship.

Ethical approval All procedures performed in studies involving human participants were in accordance with the ethical standards of the institutional and/or national research committee and with the 1964 Helsinki declaration and its later amendments or comparable ethical standards. 
Informed consent Informed consent was obtained from all individual participants included in the study.

Conflict of interest The authors declare they have no conflicts of interest.

\section{References}

Adler PA (1998) Wheeling and dealing: an ethnography of an upper-level drug dealing and smuggling community. Columbia University Press, New York

Albers-Miller ND (1999) Consumer misbehaviour: why people buy illicit goods. J Consum Mark 16(3):273-287

Antonopoulos, G.A. and Hall, A. (2016) 'Gain with no pain': anabolic-androgenic steroids trafficking in the UK’. Eur J Criminol, online first, doi:10.1177/1477370816633261

Antonopoulos GA, Papanicolaou G (2014) Unlicensed capitalism, Greek style: illegal markets and 'organised crime' in Greece. Wolf Legal Publishers, Nijmegen

Attaran A, Bate R, Kendall M (2011) Why and how to make an international crime of medicine counterfeiting. Journal of International Criminal Justice 9:325-354

Bate R (2008) Making a killing: the deadly implications of the counterfeit drug trade. AEI Press, Washington, D.C. Bate R (2012) Phake: the deadly world of falsified and substandard medicines. AEI Press, Washington DC

Beare M (2003) Organised Corporate criminality: corporate complicity in tobacco smuggling. In: Beare ME (ed) Critical reflection on transnational organised crime, money Laundering, and corruption. University of Toronto Press, Toronto, pp 183-206

Beare, M. and Naylor, R.T. (1999) Major issues relating to organised crime: within the context of economic relationships. <http://www.Ncjrs.Gov/nathanson/organised.html> retrieved April 12, 2007

Blackstone EA, Fuhr JP Jr, Pociask S (2014) The health and economic effects of counterfeit drugs. American health \& drug benefits 7(4)

Bowman BA (2008) Transnational crimes against culture: looting at archaeological sites and the "Grey" market in antiquities. Journal of Contemporary Criminal Justice 24(3):225-242

Bruinsma G, Bernasco W (2004) Criminal groups and transnational illegal markets. Crime Law Soc Chang 41:79-94

Buckley GJ, Gostin LO (2013) Countering the problem of falsified and substandard drugs. National Academies Press

Cederström C, Spicer A (2015) The wellness syndrome. Polity, Cambridge

Chika A, Bello SO, Jimoh AO, Umar MT (2011) The menace of fake drugs: consequences, causes and possible solutions. Research Journal Medical Sciences 5:257-261

Cordell VV, Wongtada N, Kieschnick RL (1996) Counterfeit purchase intentions. J Bus Res 35:41-53

Crary J (2014) 24/7: late capitalism and the ends of sleep. Verso, London

Davies P, Francis P, Jupp V (2011) Doing criminological research. Sage, London

Decorte T, Zaitch D (2010) Kwalitatieve methoden en technieken in de criminologie. Acco, Leuven

Dégardin K, Roggo Y, Margot P (2014) Understanding and fighting the medicine counterfeit market. J Pharm Biomed Anal 87:167-175

Delval, P. (2015) 'Counterfeit Medicines’, Défis: Le Intelligence Stratégique au Service de la Compétitivité, No $5,14-21$

Desmond M (2016) Evicted: poverty and profit in the American City. Penguin, London

Di Nicola, A., Martini, E. \& Baratto, G. (2015) FAKECARE: developing expertise against the online trade of fake medicines by producing and disseminating knowledge, counterstrategies and tools across the EU. eCrime Research Reports No.2. Trento: eCrime - University of Trento

Edwards A, Levi M (2008) Researching the organisation of serious crime. Criminology \& Criminal Justice 8(4):363-388

European Monitoring Centre for Drugs and Drug Addiction (EMCDDA) (2016) European drug report 2016: trends and developments. Publications Office of the European Union, Luxembourg

Europol (2008) Organised crime threat assessment. Europol, The Hague

Evans-Brown MJ, McVeigh J, Perkins C, Bellis MA (2012) Human enhancement drugs. The emerging challenges to public health. Liverpool John Moores University, Liverpool

Falzon MA (2009) Multi-sited ethnography: Theory, praxis and locality in Contemporary social research. Routledge, London 
Gilbert D, Walley T, New B (2000) Lifestyle medicines. Br Med J 321(7272):1341

Hall S (forthcoming) Ethnographic research in criminology. In: Francis P, Davies P (eds) Doing criminological research, Third edn. Sage, London

Hall A, Antonopoulos GA (2015) License to pill: illegal entrepreneurs' tactics in the online trade of medicines. In: van Duyne PC, Antonopoulos GA, Harvey J, Maljevic A, von Lampe K (eds) The relativity of wrongdoing: corruption, organised crime, fraud and money Laundering in perspective. Wolf Legal Publishers, Nijmegen, pp 229-252

Hall A, Antonopoulos GA (2016) Fake meds online. The internet and the transnational market in illicit pharmaceuticals. Palgrave Macmillan, Basingstoke

Hall S, Winlow S (2015) Revitalizing criminological Theory: towards a new ultra-realism. Routledge, London

Hobbs D (1988) Doing the business: entrepreneurship, the working class and detectives in the east end of London. Oxford University Press

Hobbs D (1998) Going down the glocal: the local context of organised crime. Howard Journal of Criminal Justice 37(4):407-422

Hobbs D (2013) Lush life: constructing organised crime in the UK. Oxford University Press, Oxford

Hobbs D, Antonopoulos GA (2014) How to research organized crime. In: Paoli L (ed) The Oxford handbook of organized crime. Oxford University Press, New York, pp 96-111

Hobbs D, Dunnighan C (1998) Glocal organised crime: context and pretext. In: Ruggiero V, South N, Taylor I (eds) The new European criminology: crime and social order in Europe. Routledge, London, pp 289-303

Hudson M (2015) Killing the host. Avalon, New York

Interpol (2014) Operation Pangea VII report. Interpol, Lyon

IRACM (2013) Counterfeit medicines and criminal organizations. IRACM, Paris

Jackson G, Patel S, Khan S (2012) Assessing the problem of counterfeit medications in the United Kingdom. Int J Clin Pract 66(3):241-250

Kimergård A, McVeigh J, Knutsson S, Breindahl T, Stensballe A (2014) Online marketing of synthetic peptide hormones: poor manufacturing, user safety, and challenges to public health: online marketing of synthetic peptide hormones. Drug Testing and Analysis 6(4):396-398

Kleemans E, Van de Bunt HG (2008) Organised crime, occupations and opportunity. Global Crime 9(3):185-197

Koenraadt RM (2012) Blauwe pillen op de zwarte markt. Een exploratief onderzoek naar het gebruik en de verkoop van illegale erectiemiddelen in Nederland. Wolf Legal Publishers, Oisterwijk

Koenraadt RM (2014) Blauwe handel. Een criminologisch kwalitatief onderzoek naar illegale erectiemiddelen in Nederland. Tijdschrift voor Seksuologie 39:8-14

Koenraadt RM (2015) Cultural criminology and the internet. Challenges for online criminological research. In: De Jong F (ed) Overarching views of crime and deviancy; rethinking the legacy of the Utrecht School. Eleven international publishers, The Hague, pp 547-564

Koenraadt, R.M. \& de Haan, M. (2016) De aankoop van geneesmiddelen via internet. Een onderzoek naar het koopgedrag, de motieven, risicoperceptie en informatiebehoefte van online kopers van geneesmiddelen. Utrecht: Willem Pompe Instituut

Lavorgna, A. (2014) 'The online trade in counterfeit pharmaceuticals: new criminal opportunities, trends and challenges'. Eur J Criminol. doi:10.1177/1477370814554722

Management Today (2013) 'The future of payments is virtual'. Management Today, January, 50-51

MHRA (2013) Press release: MHRA nets UK record $£ 12.2$ million haul of counterfeit and unlicensed medicines. Retrieved 15/7/13, from http://www.mhra.gov.uk/NewsCentre/Pressreleases/CON287024

Morselli C, Giguere C (2006) Legitimate strengths in criminal networks. Crime Law Soc Chang 46:185-200

Naylor RT (2003) Towards a general Theory of profit-driven crimes. Br J Criminol 43:81-101

Naylor RT (2004) Wages of crime: black markets, illegal finances, and the underworld economy. Cornell University Press, Ithaca

Newton PN, McGready R, Fernandez F, Green MD, Sunjio M, Bruneton C, Proux S (2006) Manslaughter by fake artesunate in Asia-will Africa be next? PLoS Med 3(6):e197

Nordstrom C (2007) Global outlaws: crime, money, and power in the contemporary world. University of California Press, Los Angeles

Ossola, A. (2015) The fake drugs industry is exploding, and we can't do anything about it. 17/9/15, from: http://europe.newsweek.com/fake-drug-industry-exploding-and-we-cant-do-anything-aboutit-333176? $\mathrm{rm}=\mathrm{eu}$

Paoli L (2002) The paradoxes of organised crime. Crime Law Soc Chang 37:51-97

Paoli L (2016) Towards a Theory of organised crime. In: Antonopoulos GA (ed) Illegal entrepreneurship, organised crime and social control. Springer, New York, pp 3-17

Paoli L, Donati A (2014) The sports doping market: understanding supply and demand and the challenges of their control. Springer, New York 
Passas N (2002) Cross-border crime and the interface between legal and illegal actors. In: van Duyne PC, von Lampe K, Passas N (eds) Upperworld and underworld in cross-border crime. Wolf Legal Publishers, Nijmegen, pp 11-41

Passas N (2003) Cross-border crime and the Interface between legal and illegal actors. Secur J 16(1):19-37

Pearson G, Hobbs D (2001) Middle market drug distribution. Home Office, London

Potter G (1994) Criminal Organisations: vice, racketeering, and politics in an American City. Waveland Press, Inc., Prospect Heights, Il

Reuter P (1983) Disorganised crime: the economics of the visible hand. MIT Press, Cambridge

Ruggiero V (1996) Organised and Corporate crime in Europe. Dartmouth, Aldershot

Ruggiero V (2000) Crime and markets: essays in anti-criminology. Oxford University Press, New York

Ruggiero V (2003) Global markets and crime. In: Beare M (ed) Critical reflections on organised crime, money Laundering, and corruption. University of Toronto Press, Toronto, pp 171-182

Schwalbe ML, Wolkomir M (2003) Interviewing men. In: Holstein JA, Gubrium JF (eds) Inside interviewing: new lenses, new concerns. Thousand Oaks, Ca, Sage, pp 55-71

Southwick, N. (2013) Counterfeit drugs kill 1 million people annually: Interpol. 26/11/13, from http://www. insightcrime.org/news-briefs/counterfeit-drugs-kill-1-million-annually-interpol

Thomsen, S.R. (1998) 'ethnomethodology and the study of online communities: exploring the cyber streets'. Information research, 4 (1). Retrieved 07/04/16, from http://informationr.net/ir/4-1/paper50.html

UN Office on Drugs and Crime (UNODC) (2013) World drug report 2013. Retrieved from https://www. unodc.org/unodc/secured/wdr/wdr2013/World_Drug_Report_2013.pdf

UNICRI (2009) Counterfeiting: a global spread, a global threat. Trends in Organized Crime 12(1):59-77

Van de Ven, K. (2016) The formation and development of illicit performance and image enhancing drug markets: exploring supply and demand, and control policies in Belgium and the Netherlands. $\mathrm{PhD}$ dissertation, Utrecht: Willem Pompe Insituut

Van de Ven K, Mulrooney KJD (2016) Social suppliers: exploring the cultural contours of the performance and image enhancing drug (PIED) market amongst bodybuilders in the Netherlands and Belgium. International Journal of Drug Policy. doi:10.1016/j.drugpo.2016.07.009

van Duyne PC (2000) Mobsters are human too: behavioural science and organized crime investigation. Crime Law Soc Chang 34:369-390

van Duyne PC (2003a) The creation of a threat image: media, Policy making and organized crime. In: van Duyne PC, Jager M, von Lampe K, Newell JL (eds) Threats and phantoms of organised crime, corruption and terrorism: rhetoric and critical perspectives. Wolf Legal Publishers, Nijmegen, pp 21-50

van Duyne PC (2003b) Organising cigarette smuggling and policy making, ending up in smoke. Crime Law Soc Chang 39:285-317

van Duyne PC (2004) Fears, naming and knowing. In: van Duyne PC, Jager M, von Lampe K, Newell JL (eds) Threats and phantoms of organised crime, corruption and terrorism. Wolf Legal Publishers, Nijmegen, pp 1-19

van Duyne PC (2005) Crime and commercial activity. In: van Duyne PC, von Lampe K, van Dijck M, Newell JL (eds) The organised crime economy: managing crime Markets in Europe. Wolf Legal Publishers, Nijmegen, pp 1-17

Vander Beken T (ed) (2005) Organised crime and vulnerability of economic sectors. Maklu, Antwerp

Venhuis BJ, de Voogt P, Emke E, Causanilles A, Keizers PH (2014) Success of rogue online pharmacies: a sewage study of sildenafil in the Netherlands. Br Med J 349(7965). doi:10.1136/bmj.g4317

Venhuis BJ, Zwaagstra ME, van den Berg JDJ, van Riel AJHP, Wagenaar HWG, van Grootheest K, Barends DM, de Kaste D (2011) Illicit erectile dysfunction products in the Netherlands. a decade of trends and a 2007-2010 product update. RIVM, Bilthoven

von Lampe K (2007) Criminals are not alone: some observations on the social microcosm of illegal entrepreneurs. In: van Duyne P, Maljevic A, van Dijck M, von Lampe K, Harvey J (eds) Crime business and crime money in Europe. WLP, Nijmegen, pp 131-156

von Lampe K (2016) Organized crime: analysing illegal activities, criminal structures and extra-legal governance. Sage, Los Angeles

von Lampe K, Johansen PO (2004) Organized crime and trust: on the conceptualization and empirical relevance of trust in the context of criminal networks. Global Crime 6(2):159-184

Wertheimer AI, Wang PG (eds) (2012) Counterfeit medicines volume I: Policy, economics and countermeasures. ILM, Hertfordshire

Winlow S (2001) Badfellas: crime, tradition and new masculinities. Berg, London

World Health Organisation (WHO) (2012) Substandard/spurious/falsely labelled/falsified/counterfeit medical products: report of the working group of member states. WHO, Geneva

Yar M (2006) Cybercrime and society. Sage, London 
Yar M (2008) The other global drugs crisis: assessing the scope, impacts and drivers of the global trade in dangerous counterfeit pharmaceuticals. International Journal of Social Inquiry 1(1):151-166

Young SN (2003) Lifestyle drugs, mood, behaviour and cognition. J Psychiatry Neurosci 28:87-89

Young J (2004) Voodoo criminology and the numbers game. In: Ferrell J, Hayward K, Morrison W, Presdee M (eds) Cultural criminology unleashed. Glass House, London 